\title{
THE RULE OF LAW IN OUR CASE-LAW OF CONTRACT $\dagger^{*}$
}

\author{
BY K. N. LLEWELLYN
}

OuRS Is a legal system in which it is peculiarly difficult to reach agreement on what the Rule of Law is. I refer to the case-law portion of our law. Where we have a statute, we know at least what its words are, and we know that its language constitutes an authoritative direction to the courts, and we recognize that it can have authority as a rule, even when its language is flatly at variance with anything which courts have said or done in the circumstance. Our legal techniques and our theories about them are indeed somewhat muddy as to statutes: cheek by jowl sit the principles about statutes in derogation and about remedial statutes, and it is a stout man who on any given issue can use both at once on the same statutory language.

But in the field of case-law with which our general theory of rules of law has been most concerned, even the sureness about what the precise

This article and its successors exploring portions of the case-law of Contract are dedicated to Arthur Linton Corbin, my father in the law. I suspect that the papers do little more than spell out and test the implications of thirty or so of the pargraphs which, these twenty-five years, he has been planting like acorns in little-noticed sections of his work.

\#The discussion of case-law in this paper builds on my Brasmoz Busz, especially those second to fifth chapters which anti-realists find it unnecessary to read as they cite page 3 of that book; and on my Präjudizirnrecer, and my SAlEs. Once a man starts reading cases to study their ways of going round, rather than their doctrine merely, the same cases take on new light and new excitement year by year. Things about the warranty cases which I printed in 1930 with some blithe assurance of printing truth have proved to require further corrective study. Compare SALEs, c. III with On Worranty of Quality, and Society (1936) 36 CoL. L. REv. 699, (1937) 37 Cor. L. REv. 341. One of the major problems is that of achieving balance not only in perception, but in communicable statement, between various aspects of the matter which current writing hides under an overly simple attribution to the words of a "rule of law" -almost any "rule of law"-when in fact only a right good, well-carpentered rule of law will in a case-law field achieve those things-notably a clean guidance and a moderate predictability. The further papers will go further into this, in Contract. For a beginning, see Warranty, supra; Through Title to Confract and a Bit Beyord (1938) 15 N. Y. U. L. Q. REv. 159, and the forthcoming companion study on Purchase for Volue.

†rofessor of Law, Columbia Law School. 
zuthoritative words are (which give the whole tone to a Continental discussion of rules) is almost wholly lacking.

To begin with, the verbal form of a rule of case-law is rarely fixed. The same judge who announces "a rule" as "long-established and clear" will often enough phrase "it" three different ways in the same opinion." In the very fact that this does not startle us lies a key to the degree of implicit fluidity of case-law rules. Similar troubles about fluidity and indefiniteness lie in the common practice of throwing make-weight arguments into an opinion after the "controlling" rule has been laid down."

\section{The Protean Correctness of "The" Rule Based on Precedent}

The fact is that there is not to be found in our system any clear and definite single relation between the cases and the Rule of Case-Law. ${ }^{3}$ We have instead a number of relations, any and each of which is authoritative and correct if the court chooses to use it. The correct doctrinal possibilities of case-law are hydra-headed, in the most settled field. It is the probabilities which move within a much narrower range, and which give guidance to counsellor and court. But the probabilities turn not on the fixity of doctrine, but on the relative predictability of courts' reactions to new cases. This is known to all of us, in our fingers. We work with the actual nature of case-law. But our technique of describing our goal and our work is not abreast of our working skills.

Let me set down a series of relations between the cases and "the" rule of case-law which judicial practice establishes as correct.

(1) The controlling rule of the precedent is the ground on which the court chose, explicitly, to rest the decision."

1. Jones v. Just, L. R. 3 Q. B. 197 (1868), is a leading case on a vital point, the implication of some obligation to give something more than minimum satisfaction of the description-words, in the case of present sale to arrive of absent goods afloat. The opinion gives "the rule" arrived at in at least four different versions of widely varying implication.

2. Compare Nebraska Seed Co. v. Harsh, 98 Neb. 89, 152 N. W. 310, L. R.A. 1915 F. 824 (1915), where, after arriving at the conclusion "No offer," the court technically destroys the full force of that ruling by a technically defective argument that, anyhow, there was "No acceptance."

3. There is emotional power in the ideal of there being some one relation. Sce Appendix, p. 1270.

4. "It is true that Lord Cottenham might have decided that case without deciding the point raised in this. But it appears to me equally true that he did not do so, that he preferred to rest and did rest his judgment as to one of the matters of exception before him upon a principle which embraces and governs the present case." Thesiger, in Household Fire Ins. Co. v. Grant, 4 Ex. D. 216 (1879). This and the corresponding cites are intended only to remind that the lines of thought concerned can wear tails and a white tie, and be received. Each line could be heaped up, if there were any point in heaping. 
(2) The controlling rule is broad enough to include the theory of an institution laid down expressly in the opinion (as that a director is " $a$ trustee").$^{5}$

(3) The controlling rule is any rule or principle "necessary" to the decision, whether or not explicitly laid down. ${ }^{\circ}$

(4) The controlling rule extends, whatever the court chose to rest its decision on, no whit beyond what was "necessary" to the decision."

(5) The controlling rule is what some later writer bas said it is-be he court or encyclopedia-and whether or not his statement is accurate.

(6) The controlling rule is anything a court has said, though in flagrant obiter. 8

5. Snelling v. Arbuckle, $104 \mathrm{Ga} .362,30 \mathrm{~S} . \mathrm{E} .863$ (1893); In re Hawkeye Oil, 19 F. (2d) 151 (D. Del. 1927). See Klaus, Sale, Agency and Price Majulcuance (1928) 28 COL. L. REv. 312, 441.

6. This was Ames' way of working. A good example is Cornell's treatment, in Merchant v. Woods, 27 Minn. 396, 7 N. W. 826 (18s1), of Palmer v. Bates, 22 Mfinn. 532 (1876). Cornell finds "decided" by the earlier case a point which the earlicr case was exceedingly careful to distinguish as not being there before the court to be decided. The "precedent" was welcome. In Webster y. Fall, 266 U. S. 507 (1925), the preeedent was not welcome, and we hear in a dictum from Sutherland that questions hidden in the record and not thoroughly argued and considered, etc., etc.

7. In Assets Realization Co. v. Clark, 205 N. Y. 105, 98 N. E. 457 (1912), Hiscock does as pretty a job along this line as $\mathrm{I}$ have seen. It is scrupulously accurate, and fair to prior authorities as few opinions are fair. But its resulting formulation of The Rule is new. Contrast Jones v. Just, L. R. 3 Q. B. 197 (1868), where the purported process is the same, but the authorities canvassed are-for reason-twisted out of all recognizability. Data collected in my SALES 262.

The familiar signal is: "The true rule seems to us to be ..." A pronouncement which follows that introduction may or may not square with any prior language; it never has to. More cleanly articulated, because more definitively stamped with conscious craftsmanship, is likely to be the whittling procedure. For instance, Swan: "A clese examination of the cases, however, does not in our opinion establish such a case." (Mry italics). The cases have been studied. They have been studied "closely." Their language, and language written about them, has been re-studied. "In none of them is the situation: the same as in the case at bar." (My italics). Then come words of policy which are not merely words: "We can see no justification . . . No intelligible reason has been suggested ..." Southern Pacific Co. v. Globe Indemnity Co., 21 F. (2d) 283 (C. C. A. $2 d, 1927)$. An extreme type of this procedure is the reexamination of the foundation of the cases about to be thrown out, instead of opening with the formula: "If the matter were res integra ..." An excellent instance is Pelletier v. Dupont, 124 Me. 269, 128 Atl. 186, 39 A. L. R. 972 (1925).

An excellent instance of the setting up of a new rule out of the cases, with conscious shaping to fit perceived policy, is Shear Co. v. Currie, 295 Fed. 841 (C. C. A. 5 th, 1923). Another, is the return to the text of the Statute of Frauds, in a situation which precedents seemed to have overiaid. Sleeth v. Sampson, 237 N. Y. 69, 142 N. E. 355 (1923)-with which compare Stone's prior reading of the precedents, in The "Equilable Mortgage" in New York (1920) 20 CoL. L. Rev. 519, 522.

8. Compare the treatment in Lagumis v. Gerard, 116 Mfisc. 471 (1921) of the remarks and qualifications in Harris v. Shorall, 230 N. Y. 343,130 N. E. 572 (1921), which found welcome in the Lagumis case and were then whitted away in Croviley 
(7) Nothing can be the controlling rule which has not been phrased in quotable words.

Now it may be said, and I doubt not that it will be said, that at least the last three of these propositions are bad law, bad doctrine, and the mark of incompetence. To this I can answer only that they are part of the multiple going ways of case-law. If the fifth proposition does not have meaning, for instance, I cannot understand the indexing of opinions in which a case is said to have been "explained," nor the frequence of citation of Cyc. and Ruling Case Law as giving "the rule." If the seventh does not have meaning, I cannot understand the desperate search for quotable language for a brief, nor the pronounced feeling among good lawyers and poor lawyers alike that to set up new language, though it holds the actual decisions to perfection, is to buck extra danger in most courts. Where courts work under time pressure, or with limited library facilities, or both, these last three propositions will be potent parts of the available alternatives for determining "the Rule" from the cases.

In a word, if one is to see our case-law system as it lives and moves, one must see that the relation between the rule and the cases may move all the way from copying any words printed by anybody in a "law" book to meticulous re-examination of precise facts, issues, and holdings, in total disregard of any prior language whatsoever. ${ }^{\circ}$ And any degree or

v. Lewis, 239 N. Y. 264, 146 N. E. 374 (1925), in which they had come to appear unwelcome.

"The remarkable opinion of Kennedy, L. J., illuminating as it does the whole ficld of controversy, relieves me from the necessity of saying much upon the subject." Loreburn, L. C., in Clemens Horst v. Biddle [1912] A. C. 18. This means to me that Kennedy's remarks upon background, theory and practice of c.i.f. cases, including much which could not have been decided in the case before him, has been made semi-authoritative. Consider the sweeping infuence of the theory of "the" bill of lading and its transfer, in Shaw v. Railroad Co., 101 U. S. 557 (1879) - all of which was dictum or obiter, and to all seeming directly contrary to statutes not challenged as unconstitutional. Or consider the much discussed dictum in Pinnel's case.

"I would rather have a Connecticut dictum than a holding from outside-except maybe New York or Massachusetts" remarked Judge Gager of the Connecticut Supreme Court, which at the time was at its best.

If one has to formulate a rule, the new formulation tends to appear to most judges and most writers as "novel" doctrine: it is, moreover, hard work to check up on; it takes time. No wonder there is search for apt language-from whatever "legal" source.

9. Finally, and vastly harder to state, is another relation thoroughly ingrained in the practice of courts, counsel, and curricula: The controlling rule of the precedent turns not on the precedent's facts, but on its artifacts: on the generalized statement of "the facts" which is left after the court has finished its "construing". The bearing of this I shall develop later. The bother of it as a way of working lies in those instances in which the artifacts, when produced as the basis for decision, already contain the legal conclusion, so that attention is drawn off from what the prior courts did with the coses before them.

"Whatever apparent divergence in or contradictory application of this rule may appear in the decision of individual cases is not due to a failure to recognize this rule 
kind of operation within that lordly range is correct, doctrinally, if doctrine be taken to a description of what authoritative courts are doing with and to cases and rules, and doing with effective authority. ${ }^{10}$

Now it is not here urged that any one or more of these working relations between the rules in a case-law field and the prior cases in and around that field is The Correct Relation. ${ }^{11}$ Each, on authority, is $a$ dogmatically correct relation. I do think certain of them more serviceable than others; but that is not at this point under discussion. It concerns me here to invite any lawyer or judge to canvass in his own mind whether he has not used and is not now prepared to use ANY ONE of these ways which may serve his need, in locating or building a rule based on case-law; and whether he is not aware, as he uses any of them, that his procedure is proper, and in accordance with the established authoritative tradition of our case-law scheme. Patently he cannot use all of the ways at once on any given precedent as to any given issue; but he can and will use several or most of them on any body of cases some of which have language which tends as he wants it, some of which have language which distresses him. He will "line these up." One piece of pure dictum will "admirably state the true theory;" an opinion his way

as universally applicable. The difference in decision was due only to the results obtained by an effort to apply the recognized rule to the particular case. The case now before us presents in the decision of the Afunicipal Court and of the Special Term on appeal another instance of the directly opposite conclusions at which different courts will arrive in applying this recognized rule to the interpretation of the same contract, and in each case the conclusion of the court is supported by a well-considered opinion." Gail v. Gail, 127 App. Div. 892, 112 N. Y. Supp. 596 (4th Dep't 1908) (my italies). This means to me: the rule depends on what people, and particularly judges, say the rule is, even though that saying gives no guidance to the holdings, present or future.

10. Well brought out by Oliphant, $A$ Return to Slare Decisis (1923) 14 A. B. A. J. 71. The nature of inductive generalization is to be multiple and unlimited, in point of authority to be claimed. Only a later case which refuses effect to a given line of generalization, or present horse-sense in foreseeing such refusal, can guide among the possibilities. The whittling down process is of course the most clearly rationalized one See illustrations in Note 7. It is nowhere more judicially articulate in motivation and method than in First National Bank of Wapakoneta v. Brotherton, 78 Ohio St. 162, 84 N. E 794 (1908), an old rule disapproved, but to be accepted as established; then deliberate and skillful quest for a distinction. But can any case-lawyer doubt that if the old rule had looked like a good rule, Baily v. Smith could have "firmly established" that "equities" of any kind persisted in the mortgage? For instance, in Bryant v. Isburgh, $13 \mathrm{Gray} 607$, 74 Am. Dec 655 (Mass. 1859), a rule is derived from "the law of this commonwealth, understood and practiced on for more than forty years," and authority produced at length by the simple process of manipulating the word "adjudged" in place of, say, "necessarily decided," and of noting that lines of unnecessary language had "taken no distinction." See my Sales 219, et seq.

11. Any art of dealing with moving life by use of authoritative materials conccived to be relatively static has to develop either supercraftsman or a multi-headed set of technique. The only road out is recognition of a larger range of flexibility in the materials. See Bramble Bush, cc. IV, V. Koran, Constitution and eases are here alike 
which quotes that dictum will become "the leading case;" two opinions with less happy language will buttress his present case by their facts and decision, but will not be quoted from; one case announcing a contrary rule will be distinguished as not involving the point here at issue; another whose raw facts were almost identical will be pseudo-distinguished because the artifacts were different ("That was a case of an agency"); and any text that can be used, whatever it rests on, will be thrown in as showing the rule claimed to be "well-established." 12

In very sooth, there are a number of recognized authoritative relations which prevail between the rule of law which rests on case-law and the past decisions on which the rule purports to rest, and on which it is supposed to rest. And these recognized and authoritative relations are frequently semi-inconsistent, or wholly inconsistent with one another. Here lies the heart and juice of the matter: the various established and authoritative relations between the rule and the cases lead to different rules. These different rules, loosely formulated, or reformulated more precisely, or latent and never yet expressed, are in open or covert competition, and our going doctrine, both formulated and unformulated, about how to locate or build a rule gives no clear criterion at all about which rule is The Rule. There is one test, however, which in the long run we all use to determine the rule of law in a case law field. That test is in first instance the test of how future cases will come out. ${ }^{13}$

If it is moderately clear how future cases will come out, then a statement of that clarity is the Rule of Case-Law, and it is the Rule, irrespective of whether it is a nice rule or a wise one or a just one. And it is also the Rule, irrespective of whether there are pseudo-rules lying around which purport to be The Rule, but are not. Doubt begins when it is not clear how future cases will come out; for instance, because the accepted formula does not effectively guide decision at all, or because the courts use it some of the time, but avoid its implications some of the time-situations which I hold to be more typical than non-typical of such fields of case-law as the law of Contract.

All of this leads to doctrinal difficulties. "Ours is a legal system in which"- on the case-law side- "it is peculiarly difficult to reach agreement on what The Rule of Law Is."

12. For a classic instance see Miller in Staiger v. Soht, 116 App. Div. 874 (2d Dep't 1907), commented on in On Warranty of Quality, and Socicty, 2 (1937) 37 Cor. L. REv. 341, 357. Jones v. Just, L. R. 3 Q. B. 197 (1868), whittles some authorities, stretches others, blows new meaning into both announced rule of the case and accidental dicta, with regard to others. See comment in my SAlEs 270.

13. By "covert competition" I mean to include here not only the drive of courts to get a just result by twisting, but the always latent possibility that counsel in tomorrow's case may explore one of the latent possibilities and put it across. 


\section{Accepted Formula, Consistent Practice, Right Rule, AND Principle}

We are dealing with a going scheme of things. We are dealing therefore with that rule which is, in so much of our going "system" of law as consists of case-law. Our scheme of law is that which we happen to have, not any shaping to our desire. If a rule is, it is that rule which we want to find and state.

But one of the going conventions of that going scheme is to obscure the scheme and its going by always talking as if any "rule" rather persistently announced and recited (any "well-settled rule") accurately reflects the actual course of decision, and therefore both rests accurately on the course of decision and gives accurate guidance in predicting future decision. ${ }^{14}$ A second going convention is to obscure the scheme and its going by talking most of the time as if there could be in a situation only one "true" rule." It seems, moreover, to be assumed pretty generally that if a rule is "well-settled" it is ipso facto the true rule of case-law", even if we think it impolitic and unjust; but if it is not "well-settled", then rightness, wisdom, policy enter into determining what the "true" rule is.

Between the more concrete rule about a situation and explicit inquiry into policy, wisdom, ethics (which would carry an unconventional flavor of open judicial law-making) lies the middle-ground of "principle". "Principle" permits of frank critique, of open change, and of responsible choice, within the case-law scheme. It is "principle" which can show even a "well-settled rule" to be "an anomaly" and undesirable, and deliberately "not to be extended", or even one to be openly whittled away. ${ }^{16}$ It is "principle" which can give guidance in case of doubt as to the "true" rule. ${ }^{17}$ And the philosophy of "principle" in our case-law

14. I go with Radin in the essence of his proposition that the Rule is (at least for our case-law) what a court will say it is. THE LAy AND MR Surtr (1938). But I should partly reformulate: The Rule of case-law is an accurate statement, if one can be made, of what the court will do in the situation.

15. Whenever the doing and the saying of our case-law fail to square, each of these modes of saying obscures the problem. I find our doing and our saying in the case-law fields I study to be noticeably and importantly at odds, in places where it matters.

16. The dictum in Pinnel's Case is a classic example, but is misleading in that the much more frequent phenomenon is to whittle harder, and more efficiently. Consider the fate of the constructive performance "anomaly" in personal service cases; or the brusque dismissal of Mansfield's supposed ruling that a writing would do instead of a consideration; or the Wisconsin court's repudiation on principle of a recent ruling of its own, in Knight \& Bostwick v. Moore, 203 Wis. 540, 234 N. W. 902 (1931).

17. But "principle," where "there is much confusion and even some conflict in the cases" will lead with equal propriety to preferring a majority rule, or a minority rule, as in the diverse opinions in National Importing and Trading Co. v. Bear, 324 Ill. 346, 155 N. E. 343 (1927); or a reconciling rule, as with Cardozo's opinion in Imperator 
is this: It purports to rest on case-law, and so can claim Authority. It purports to rest on wisdom and ethics, and so can claim to lead to good policy. ${ }^{18}$ It purports to rest on a base both broad and good, and so can justify departures or extensions in any narrower field. It has a traditional flavor of being a major premise, and so fits the traditional manner of case-law speech about reaching a decision. ${ }^{10}$ Its inherent purpose is to guide amid confusion, so that it escapes check-up against any inconsistent data of decision: such are "unsound on principle" and can be disregarded. ${ }^{20}$ Its actual use almost never involves a formulation sharp enough to mark boundaries, or even cores of tendency, so that its wisdom as a formulation is not subject to check-up; it is enough for the most clear-eyed opinion to say that "We do not think the principle extends that far." 21 Half or more of the time there is no formulation of any specific principle at all when a decision is announced "on principle." 22

Realty Co. v. Tull, 228 N. Y. 447,127 N. E. 263 (1920), or a rule built upon lines of wholly novel insight in the narrow field, by borrowing from some broader line of generalization available elsewhere, as in Ungerer v. Louis Maull Cheese \& Fish Co., 155 Mo. App. 95, 134 S. W. 56 (1911).

18. Which gives the current phrasing "to rest on the better reasoning and to be sound on principle and on policy" its quota of juice, even when no mention is made of either the principle or the policy. My loose judgment is that the principle in question is more frequently cited or stated when it leads to affirming a rule to which it lads; but that the policy is if anything more commonly stated when it tells against a rule.

19. But it is not case-law practice to reason closely from any principle as a major premise. E.g., "The court cannot make contracts for the parties" does not ever, in a regime of constructive conditions, need to lead to the rule or rule semi-rested on that "principle." And I think in this looseness of use of anything called "principle," as a premise, lies one of the more important utilities of the concept. It docs free action from too close check-up.

20. Since the intellectual office of case-law principle is to bring some guidance out of confusion, principle always has genesis in partial disregard of authority. Ames' formulation of the bona fide purchase for value principle as an utterly general principle, in (1887) 1 HARV. L. REv. 1 of course forced attack on some authorities as being wrong. It is more troublesome that this same line of origin, together with the lines of use of the principle-concept in case-law, tends to keep an alleged principle from periodic recanvass of authorities to test its title to the title.

It is, I hope, clear that I am talking here about much more frequent and fundamental case-law phenomena than that of "competing principles."

21. See Hines v. N. Y. Cent. R.R., 231 N. Y. 229, 131 N. E. 898 (1921). Similarly, even amidst the careful craftsmanship of the opinion in Alleghany College v. National Chautauqua County Bank, 246 N. Y. 369, 159 N. E. 173 (1927).

22. Williston's writings on Sales and Contracts offer instances many of which will require discussion in the succeeding papers. The gradations run from resting on principle not even expressed through resting on some principle so broad as to call up only vaguely an intelligible line of choice (as in the "He who has permitted the fraud" cases) down to a situation where even an unexpressed principle shows quite clearly the policy foundation which is in the court's mind. The various opinions in Canavan v. City of Mechaniesville, 190 A. D. 252,180 N. Y. Supp. 62 (3d Dep't 1920) and 229 N. Y. 473, 128 N. E. 882, 13 A. L. R. 1123 (1920) run almost the gamut of implicit and explicit possibility. 
For all of these reasons "principle" is a concept incorporating for our case-law scheme all the virtues which in our fonder moments we see in that scheme as co-existing: authority out of past decision, systematic order, certainty, simplicity, and rightness. Incorporating all of these ideas at once, being vague, and inherently resisting any attack from decision, fact, or policy, because it is itself (by virtue of being "principle") inherently right, "principle" becomes an ideal vehicle for moving without discussion, and without full acceptance of responsibility, into preferring any one of the multiple virtues of the case-law scheme over any other of those virtues whenever any two (or more) of them happen to be in conflict. 23

This it is important to perceive. But it is more important to kecp it in mind; for in its little way and lesser range the concept of "true rule" operates much along the same lines as does "principle."

And it goes without saying that broad and untested generalization an be involed, and is, without being called "principle." Yet if one compares In re Cohen, 15 F. Supp. 690 (S. D. N. Y. 1936) where "principle" is invoked without precise indication of why and, this time, to emasculate any result to which any intelligible preferred frinciple ought to lead, with State St. Furniture Co. v. Armour \& Co., 345 Ill. 160, 177 N. E. 702, 76 A. L. R. 1298 (1931), in which principles aplenty are stated, but are not called such, though stated very broadly, then I think one cannot help but see the gain in clarity derived from precision in the statement of motivating policy, and the further gain derived from stating such policy not as "principle" merely, but on its legal and, where the case admits, on its policy base. I like neither decision. But the former one leaves me the whole job to do: to discover why do I not like it; to discover what are the very lines of my divergence; and so on from there. The latter gives lines of divergence clear to see. This offers courts protection, in making case-law decision. But a serious query is whether such protection is not becoming more unnecessary, as information about the nature of case-law grows. I cannot see that those courts which become more explicit lose effect or standing.

23. The text presents a description, not an evaluation, of one major use of the principle-concept in our case-law. I have certain evaluations. One is found in Essays on Research in the Social. Sctences (1931) 89. I.e., until the inherent necessity of occasional creation in the judicial job becomes frankly faced on all hands, there will continue to be time-pressure and circumstance-pressure to use all the accepted techniques, including that of appeal to vague or vaguest "principle," to get things done as they seem needed to be done. And if we cannot get the necessity for leeway faced, then obfuscation is simply what we have to pay for movement.

A second lies here: guides in a situation still doubtful or not adequately explored are needed, often desperately. And one can often find lines of guidance which look very good, even when their edges are most uncertain. "Principles", like "standards," do a good and needed job in such a situation, whatever their misuse may do in other situations.

A third lies in a modification of the first: if rules tend, as they do tend, to freeze too hard upon what has been either done or said, and justice is, as it is, one equal part of the judge's job, and judges and lawyers tend to feel, as many do, that continuity is a vital feature of the ultimate workability of the very legal system, then devices (like the "principle" concept) which allow or even further important movement without costing undue doubt and felt uncertainty are worth considerable cost in unclarity and uncertaints not consciously perceived as such. But I think this very different from my first evaluation. For this one might be permanent in incidence. 


\section{True Rules of Case Law}

Now in the field of rules built on case-law we find a number of phenomena which it is well to look at, all at once. Their mutual bearings may puzzle us a bit, but puzzlement is the first step beyond discomfort into cure. There.is "conflict", there is "confusion." 24 Both terms refer commonly to division among authorities in regard to stating "true" rules. Less frequently discussed are two other phenomena. There is often enough very considerable implicit and silent consistency in actual decision even when announced rules are at odds. ${ }^{25}$ There is often also a baffling implicit inconsistency in actual decision when some rule is regularly announced as clear and well-settled "but with difficulty in its application" ${ }^{26}$ - a lamentable exhibit, so far as certainty in law may be the desire. ${ }^{27}$ There are accepted rules which do not reflect the cases at all,

24. Both will be dealt with, in their very interesting operation, in Appendices to this series.

25. A notable exploration is Corbin's study of Contracts for the Bentefit of Third Persons (1930) 46 L. Q. Rev. 12. Oliphant's Return to Stare Decisis suggested another, in regard to contracts "in restraint of trade." See note 10 , supra. Williston's neatest jobs in the Sales Act were a discrimination in $\$ 49$, which got closer to the cases, because closer to their underlying and felt policy than either of the announced competing rules, and discrimination among diverse types of bill of lading and bill of lading situation which again lined up actual decision better than did either competing theory-and for the same reason. In both cases he felt he had created "new" doctrine. Is $\S 90$ of the Contracts Restatement, or $\$ 45$, "new" doctrine? The cases say: Both are rather belated explicit doctrine. Holmes was moved in Martin v. Meles, as early as 1901 [179 Mass. 114, 60 N. E. 397 (1901)] to indicate his appreciation of a powerful case-trend-to which that decision then contributed its mite.

26. Startling exhibits are the notes on mortgage and conditional sale in 17 A. L.R. 1421, 79 A. L. R. 937. But minor examples are the N. Y. usury decisions on personal-debtor realty mortgage for the last thirty years; the $\mathrm{N}$. $\mathrm{Y}$. warranty-in-executory-contract situation, 1876-1910; the N. Y. antecedent-debt-as-value situation in negotiable instruments, 1898-1917. On a wider scale, compare advance "payment" (new, part-new, or pure preference set-up) in its effects on the defeat of "seller's" creditors, in chattel cases. See Comment (1937) 37 Cos. L. Rev. 630.

27. May I repeat what I have suggested before [(1931) 44 Hakv. L. REv. 1222], that certainty in law is some of the time a thing to be desired far beyond the degree to which we have it, and some of the time to be avoided with even more careful use of the techniques now axailable. In terms of the degree of reliance on counsel in advance of transacting, and in terms of the degree of available balance between counsel, one finds similarities between real estate law and criminal law (anti-trust, e.g.) and dissimilarities between commercial law (written contracts) and commercial law (form-pads). And whereas business enterprisers' law is a law implicit with risk, and their legal advisers need hardly be as effective prophets as their technical advisers, and a shift in statutory taxation policy or administrative policy can be almost as catastrophic or helpful as a shift in market, yet the very introduction of the Due Process idea (which over the water has meant repeatedly heavy compensation for abrupt change) indicates that Law has as one job to temper the wind even to the unshorn ram. And it has. But Jurisprudence needs to get down to analysis, in terms not of Law-in-General, but of what 
but which, if they go on being accepted, may in time come to shape future cases. ${ }^{28}$ For believed and received formulae do have effects. ${ }^{20}$ There is, on the other hand, that persistent earthy sense of courts, that feel for the case in hand, which leads them to evade repeatedly, by reformulation, by "construing" facts out of recognizability, by finding or ignoring procedural slips, when the rule seems to call for an unjust result. $^{30}$ Again, the results are sad for certainty: for no man can accurately tell in advance when a court will, when it will not evade an accepted rule for any given particular case-in-hand; the only possible advance judgments are gross estimates of likelihood..$^{31}$ Just as no man can ac-

kind, and of where, and of when, and of how. If, for example, such counsel-using, semirealty, rule-of-property-and-contract situations as installment sale of house-and-lot to little home-owners come to be subjected to reformatory regulation with some sharpness in my State, I shall not feel Certainty of Law-at-Large to be unduly impaired.

28. Ehrlich made this point, with reference, if I remember, to the Sachsenspiegcl. His reference is to an announcement of The Law, if it or its author gets over, maling itself effective, though it was mistaken as written. Our nearest example on the grand scale is Coke. Cardozo, in the Alleghany Case, catches into true words a refinement: "The half-truths of one generation tend at times to perpetuate themselves as the whole truth of another, when constant repetition brings it about that qualifieations, talien once for granted, are disregarded or forgotten," 246 N. Y. 369, 159 N. E 173 (1927). Each states a tendency, not a "whole truth." Each tendency is perennial. Each tendency, in our case-law, has a full-blown counter-tendency at work beside it.

29. In Page, Cases and Readings on the Law of Contructs (1935) 10, the formula that circulars are not offers was "applied," in disregard of another, less specific, formula, that correspondence needs reading as a whole. Fifty years before, in Spencer v. Harding, L. R. 5 C. P. 561 (1870), the formula that an invitation to bid was not an offer had been "applied" to an invitation to bid for a specific stock of goods, to be inspected in advance, and for cash. See infra, on rewards, at notes 42-47. There neither is question, nor should there be exaggeration, of the phenomenon.

30. Examples must come in the following papers. Yet I will cite here the New York almost unbroken string of sound results on the facts and issues of warranty cases, despite all difference in personnel and reasoning, after 1804 until 1860. Warranly, sipra note 12. For modern results compare Comments (1937) 37 COL. L. REv. 610; 621; 630.

31. Some biologist has remarked on the difficulty about telling where a primrose would or would not grow, or whether any particular primrose would. That is the difficulty which has bothered Frank, and bothered Moore. Frank labored to make the uncertainty clear, as a fact; and to show the why of its existence (on which latter I disagree with him); and to persuade that it really shouldn't give too much bother. Moore set to work on finding techniques for eliminating the difficulty: Those who are anti-either are distressed much more about their findings of fact (about $d c$ facto unpredictability of "Law," or, better for Moore, at least of "Case-Law," or, still better, for both, of "any particular Case at Law") than they are about their explanations or lines of remedy. I am distressed about neither, but especially not about the findings of fact that uncertainty exists in legal result of particular cases, in a case-law field. Krnowing that much of it there must always be, and thinking that some of it is useful in the right places, and being sure that where it ought to be reduced, facing it will still be the first condition to its effective reduction, or to intelligent judgment as to whether any particular place is the place for its reduction, I am tempted to meditate on star pitchers who do very well at .650 , star fielders who do very well at .950 and star batters who do 
curately foretell which of the multiform precedent techniques will be employed on a given precedent or body of precedents; he will make a guess-a more or less informed and skillful guess, on that-subject to the accident of what sort of case the next case may be and of how well counsel in that case may be balanced or unbalanced in relative skill. ${ }^{32}$

What is sure, however, is that not even informed guesses can be made in such matters by lawyers or writers who take a rule as meaningful merely because it is more or less uniformly formulated and recited. Its history in the outcome of cases, seen as cases, on the facts, is the minimum essential to a guess about its future effects. ${ }^{33}$ Such study of its accurate history will commonly enough lead to reformulating or utterly changing the statement of the rule. Wherever a master of our case-law has gone to work, such has been one major line and one major effect

very well indeed at .350 , if their hitting is significant when it occurs. I wonder also whether 1000 fielding, pitching, and batting could coincide, or would be worth interest if it did. If "Law" were as Certain as "It" has sometimes been overargued to be, thicre would be no room for advocates, in brief or in appellate court. And no room, in function, for courts which were not slot-machines. The job would be finished, when the facts were clear. (To my personal taste, also, there would be little interest in any part of Law.) The question recurs, therefore, on Where, and When. And then, on making things in law more certain, where they need to be made so; and more just, where that is the need; and on discussion, on which part of Law is which, and with which need, and how to go about it.

32. One of the further, and rather more peculiar, peculiarities of our case-law scheme of things is that while we honor Men by having them sign opinions, and thereby officially recognize much more than our Continental brethren the part played in Law by Mant, the Judge, yet our theoretical scheme of doctrine-making by cases comes close to ignoring the part played by another group of men, the Advocates. In an America wherc some lawyers are as definitely more skillful than others as some judges are, but where we recognize by opinion-signing and person-citing the value of knowing what particular Judge was at work, this is just plain queer. But, having a word for jury-risk, (in a case in hand) and an implicit understanding for judge-risk, (as we do our counselling) we may in due course acquire a word for counsel-risk, as to the possible cases affecting our new judgment on what will happen. Cf. Through Title to Contract and a Bit Bcyond (1938) $159,172-175$, nn. 23 and 24. Meantime, there is no single fact which speaks as eloquently to the pressure of fact and general scheme of things toward relatively predictable reaction as the persistent failure of the amazingly variegated American Bar, when serving as paired advocates, to upset too materially the expectations of the same American Bar, serving as individual counsellors.

33. U. Moore thinks such study not enough. Moore and Sussman, The Lazryer's Lazv (1932) 41 YALE L. J. 566. I have only admiration for Moore's efforts to further scientific predictability in the law. It has not been appreciated that those efforts rest in important part on the dissatisfaction of a lawyer whose actual predictive judgments on the more common basis will rival those of any lawyer in America, with that same lawyer's inability to communicate to the unskilled the ability in prediction on 'lawyers' materials" which a master has, himself, and has demonstrated. Moore has moved with all the drive of a powerful mind toward finding some way to make more predictable where primroses will grow, and whether any particular one will. And with fascinating byproducts. 
of his work. ${ }^{34}$ "New doctrine", which is merely a more accurate formulation of implicit old doctrine, then displaces old doctrine because the old doctrine had been jerry-built, and gives that aid to future prediction and decision which comes from having clarity in seeing and labelling the really significant and driving factors in a decision-situation. There is another kind of "new doctrine"-that of the advocate of reform in substance, of change in the course of decision. The two kinds are confused under the single label "new doctrine" or "true rule". They should not be. They need not be, for scholars-though no advocate would sanely pass up the chance of persuading his tribunal (in our case law scheme) that what he urged was already long-established.

With this background, I recur to the proposition that in searching for the rule of law in any situation covered by our case-law, sanity begins with recognizing the actual and existent: the course of actual decision, if there be one to recognize $;^{35}$ the range and manner of available use

34. To be excepted from this statement would be a great creative genius in a great creative period, such as the Mansfield of Kingston v. Preston, Boone v. Eyre, and Stuart $\nabla$. Wilkins. Yet even this is an exception only in incidence. Mansfield's brilliance would flicker out instead of burning, if the flashes did not guide to results on facts, as if they had been summations of prior recorded judicial wisdom.

Almost anything Corbin has written since he got his roesbulary worked out will serve as an example. But what concerns me more is that when cases really start to be peeled, then despite all differences of age and experience and point of view, workers start coming into measurable distance of one another's results. Such doctrinally conservative jobs as Hiscock's in Assets Realization Co. v. Clark, supra note 7, or L Hand's in Schwasnick v. Blandin, 65 F. (2d) 354 (C. C. A. 2d, 1933), or of Kennedy, Value-A Plea for Uniformity in New York Commercial Law (1933) 8 Sr. Jons's L. Rev. 1, or of Bacon on the receptacle cases in Sales, or of the student editor in (1938) 23 Coass. L. Q. 310 , do not quite square with the results a more impatient person-say a realistic distruster of accepted words-would bring out of the same material; but they are immediately intelligible and workable, and their attention to the cases and care with them have tremendously narrowed the field of possible difference even of opinion.

35. It does happen that the "true rule's" flavor of rightness and reform prevents a court from taking it as true. Langel v. Betz, 250 N. Y. 159, 164 N. E. 890 (1928), sees the Restatement as "proposing a change," "a complete reversal of our present rule of interpretation"-"perhaps, more in harmony with modern ideas of contractual relations." "But the law remains." Similarly, it is repeatedly said of a writer or notewhether in opinions or in other writers or notes-that $\mathrm{X}$ has proposed such a rule, but no case has been found supporting it.

We have here, as stated in the text, a clean confusion, with a resultant possible head-on collision. If the alleged rule contended for looks to a reform of the course of action of courts, it is indeed suspect as a statement of case-law, and has only such claim to standing as "reason" and "principle" may procure for it. Often that will b. enough: more often, it will not. But if the alleged rule contended for is an unconventional but accurate statement of the past course of action of courts, there is vide warrant in authority for accepting it not as alleged novel doctrine, but as discovered true doctrine. It is supported not by $a$ case, but by the cases. But there is the countertendency to see as "the" rules only accepted and familias forms of vords. 
of announced doctrine, which is always there to recognize, but which gives in some fields a recognizably greater leeway, a recognizably lesser impulse in any particular direction, than in some others.

The ideal rule of law in case-law will be that which

(1) fits rather accurately the actual recorded outcome of a rather consistent body of cases examined as cases, on facts and result; and

(2) is announced in those cases as the rule; and

(3) appeals today as leading to a just result; and therefore

(4) offers real hope of appealing to present day courts; and so of guiding them with some sureness; and so of affording a counsellor a moderately accurate prediction, and an advocate a solid basis of case-planning.

There are some such rules of case-law. There are not too many of them. Their number is much smaller than we are inclined to think. Of this the proof is simple. Turn to any skilled specialist in a field in which you are not a specialist, and tell him of the rules which you "know" to be "well-settled" in his field. In five cases out of ten, and more probably in eight or nine out of ten, you will end by hearing a more accurate formulation of a rule more closely approximating the demands of the first characteristic or the second characteristic or (and more probably) a shrewd omelette of both which has ceased to be quite either, than anything available to you. For what is available to you as a non-specialist is the accepted patter of the field-that semi-emptiness which is currently regarded as "the rule".

It will be observed that of the four characteristics of the ideal rule in case-law, set forth above, the fourth is a resultant of the coincident presence of the first three. It adds nothing, if the first three be present together. But it is worth stating. For it will further be observed that wherever the first three are not all present together the problem of the fourth not only opens, but subdivides: for prediction, not critique of wisdom, is the base-line job of the counsellor; whereas the judge has as one of his two base-line jobs to get a wise and just result. ${ }^{36}$ I think it follows from this that where the first three characteristics mentioned fail to appear together, the rule of case-law for the counsellor must at times diverge from the rule of case-law for the judge; but I shall try to show that this divergence is less than would at first sight appear. ${ }^{37}$

36. See Appendix, p. 1270.

37. I disregard here the advocate. He is like a counsellor, so far as he is planning what any line of proposed doctrine will carry, in weight for the situation in hand. He is unlike, in that he is about to undertake his own shaping of the persuasion element in decision. But we can disregard him here, because any moderately accurate statement of rules for counsellors will be guide enough for the advocate: he needs to see what 


\section{Rules for Counseliors and Rules for Judges}

Briefly, the lines of the argument are these: The first characteristic is the utterly basic one for both. A rule which states accurately the outcome of the cases, seen as cases, incorporates pro tanto such wisdom on the cases as prior courts have shown, and such similarity of reaction as courts are likely to continue to show. Insofar, it does some discounting (for the counsellor) of what later judges are likely to think wise and right; and gives some guidance (to the judge) about wherein his more personal judgments on such matters may be wisely tempered. It further sets (for the judge) an indication of what have been the lines of actual use of whatever doctrine was current, indicating both the range of leeway which such doctrine allowed and any clear trends within the leeway which have proved to grow. ${ }^{38}$ This sets the picture of how far he is or is not really free to move unimpeded, and shows where the penumbra of his honest freedom lies to make further use of the given multiple case-law techniques. If the rules announced in past cases or in the books are substantially at odds with the decisions, counsellor and judge need alike to know that: the counsellor because he cannot then trust the rules announced; the judge because it is his job to ponder whether to follow the announced rules or the past courts' actions or some modification.

Serious discrepancy between the rule for the counsellor and the rule for the judge begins when there is no effective consistency to be found in past decisions, no recognizable coursc of decision. Then the judge wants a rule of wisdom, whereas the counsellor's job becomes one of gambling on what will appeal to whatever court may get the case as wise -as being the "true" rule. In such a situation there is more likely than not to be for the counsellor no worthwhile rule at all-and it is as well to recognize that fact. ${ }^{39}$ What there is, is a set of competing rules strug-

there is of certainty, and what there is of leeway. Onec he has talsen his case, policy becomes of little moment to him, save as a persuasive tool.

38. It is in the range and limits of ase of freedom to move that the heart of our system lies. What keeps a judge sitting "at law" but under a Code, from giving a conditional judgment which is called for? On the other hand, what makes it unthinisable that a sturdy dissenter could not force through the publication of his signed dissent? In such situations, "cannot" and "must" are silly words. We have a given practice, we have a semi-conscious judgment that departing too far from it would somehow be wrong, and we have a judgment very conscious indeed that wrongness is not what we are going to do.

39. This does not mean that I think that without practice there is no law, nor that I think law must follow custom, even when custom is silly or wrong. It means, instead, exactly what it says. For the counsellor, a rule is a basis to go on. If there is no basis to go on, then, for the counsellor, there is to that exact extent no rule in the legal system at hand. Only uncertainty in outcome of cases is gained by "secing" counsellors' rules where they do not exist. Purported "rules" which merely might be used and then put over in court, are another matter; they are advocates' tools and counsellors' possibilities. 
gling to control the judge, with our case-law giving little guidance to prediction, save as it illumines the nature of our case-law personnel.

To sum up thus far: we are all agreed that case-law rules must be based to some extent on prior cases, and the more of the cases there are, the more so; but we have evolved and established a large number of discrepant relations between a rule and its prior cases, resulting in discrepant techniques in working from the cases to the rule. All of these techniques and relations are "correct", because they are all part of the case-law going scheme, which is an authoritative scheme, as most who attempt to buck it will discover. Like the techniques for finding the rule, the ideals of the case-law scheme itself are diversified and often inconsistent. The concepts of "principle" and of "true rule" seem to incorporate various inconsistent ideal attributes at once, so as to enable silent or unconscious mediation and even choice among them.

In consequence, in any case-law field, both latent and formulated rules are in constant competition for governance. The ideal case in which judicial practice-in-fact, i.e., an actual course of decision on cases, squares with the announced rule "governing" the cases, and also with present day notions of rightness, is much less frequent than is commonly assumed; for part of the scheme of our case-law is a set of concepts and techniques which obscure and slur over the discrepancies, and induce us to think the ideal situation to be present when it is not.

The test of the relative worth of competing rule formulations lies in first instance in their accurate guidance to prediction of the outcome of future cases. Since we can only judge in the present, this test is always in the offing. The first step in approximation of a prediction is study of the past outcomes of cases, seen as cases. Where this shows relative uniformity, the chances are strong that such uniformity, wise or unwise, will continue; and a statement of whatever uniformity there may be is a statement of The Case-Law Rule, however much at variance it may prove to be with accepted superstition about what the rule is. If the accepted and "well-settled" rule varies from the course of actual decision, i.e., is superstition, then the best the superstition will accomplish in the near future ${ }^{40}$ is to unsettle a bit the relatively consistent course of decision, and continue to obscure the picture. Where no such relative uniformity appears, then any rule which purports to be absolute and clear ${ }^{41}$ has value only as a guide to wisdom, or as one factor in attempting to deal with later prospective non-uniformity and uncertainty. But the meaning of such a rule as a going part of case-law cannot be understood

40. Over the long haul, such a superstition has its chance of not going under, but prevailing. See note 28 , supra. But more important for the purpose here is the uncertainty of decision while the hidden battle rages.

41. On the value of rules stated in terms of likelihood and recognizing divergent likelihoods, see the later papers. 
apart from an accompanying presentation of what the course of decision does not show in the way of results.

In the re-study of case-law results, and their accurate reformulation, lies now, as it always has, the path of progress in case-law. Such restudy is of course not enough. The past is not the whole, nor are the decisions the whole, nor does the existence of a practice, even among judges, of itself prove the practice good or wise or necessary. But such restudy is a necessary precondition to case-law progress; and case-law progress, reduction of case-law superstition, is in these days somewhat needed.

\section{Application to the Case-Law of Contracts}

There is no field of law in which it is more needed than in Contracts. The reason lies, I suspect, in about even division at the door of accident and of the nature of the case. For the nature of generalizing and ordering synthesis of particularized and discrepant data is to force the rubbing out of attention to any discrepant particulars. Rewards, for instance, which once were simply rewards, ${ }^{42}$ become anomalies, ${ }^{13}$ and then become a form of contract, with certain resultant alterations in their accepted rules. The cases remain moderately stubborn; the statutory bounty emerges "as an exception" to recapture a portion of good sense; rewards get divided and allotted in ways very difficult to square with existing current contract theory. ${ }^{4}$ But, for the Contract theorist, at least the major fighting point becomes "established": reward is contract (unless it is not) and "communication of offer" is required and so

42. Say, in Williams v. Carwardine, 4 B. \& Ald. 621 (K. B. 1833).

43. Say, in Dawkins v. Sappington, 26 Ind. 199 (1866): "anomalous"; "an exception"; "not been seriously questioned"; good "policy" and "morality." Corbin lists cases [CASES ON CoNTracts (2d ed. 1933) $22 \mathrm{n}$. 10] where all or fart of the service had been rendered without knowledge of the offer. Note the phrasing. Note also the dates: 1862, 1866,1871, 1872, 1873, 1878; with four American cases since 1896, of which two in states with prior rulings, and one a case against the United Stztes. The challenge to the "anomaly" has effect in Tennessee by 1845, in N. Y. by 1868, N. J. 1873, Cal. 1880. But he lists six new states joining the "contract" rule after 1900. Id., at $23,25$.

44. Choice v. City of Dallas, 210 S. W. 753 (Tex. Civ. App. 1919), in adopting the bounty idea, expressly recognizes the almost utter dearth of real authority. The line of growth has just plain charm; from case-sense to non-case-based legal theory which begins to prevail over sense, but dissatisfies; thence to a compromise along a line made respectable by another acceptedly legal concept.

The originally non-case-based legal theory has now acquired its cases, and therefore stands on a footing which it once lacked. But it has not squared reward cases with the current doctrine of formation of unilaterals; the splitting of rewards, remains, inter alia, to bother. The whole matter needs exhaustive reexamination, and will get it promptly. Meantime the caution and insight revealed in the phrasing of Corbin's notes deserve their attention. 
is "intent to accept"; ${ }^{45}$ and there is no need to inquire into the meaning of the results in life or the cases. Well, perhaps there is not. Rewards are queer enough things so that perhaps any rules about them will do, and litigated rewards are queerer still, and in some fields rewards are said to be a racket. ${ }^{46}$ Still, inquiry might pay.

What grows upon the observer, as he studies "the whole field" over, and dips more particularly into any type of transaction, is a strong sus" picion that curiously many of the currently accepted rules of Contract are not, and never have been a reflection of, or a guide to, the case-law of contractual relations at large. We talk as if they were, and the courts talk very commonly (but by no means as commonly as we think they do) as if there were effective general rules of Contract. And many such there doubtless are. Such need finding and stating. We can use them. But we cannot, if our aim is certainty in guiding people, or wisdom in judging cases, afford to use pseudogeneral "rules." Mere general acceptance of a formula is not a proof of its case-effectiveness. There is not only the history of the amazing widening of generalization in the "Contract" field. There is newer trouble. Any one who has wrestled with "Contract" problems has become aware that special fields show special rules whose bumps the pumice and elbow-grease of the theorists have not yet rubbed out. ${ }^{47}$ Treatises on Contract treat some of these. There are many others which they do not treat.

45. I have met no cases establishing either point, except as a necessary consequence of some more general theory which "showed" contrary cases to be wrong on "principle." It is interesting that the principle in question was a principle based on that same supposed need of de facto agrecment which Adams v. Lindsell had long shown to be unnecessary to contractual obligation, and which has no wholly intelligible application to the "pure" unilateral, the very theory of which was developed to get rid of the type of insistence on agreement still typified in the dissent in Underwood Typewriter Co. v. Century Realty Co., 220 Mo. 522, 119 S. W. 400, 25 L. R. A. (N.S.) 1173 (1909). But, patently, theory which shapes case-law may derive from other sources than judicial language or action; and, patently, if its sources are various and its effects in shaping are, even in success, not complete, there is a problem for investigation, where certainty has importance.

46. As to jewelry, see Hald, Theft, Law, AND Soctety (1935), which both complements and is complemented by the discussion of the "fix" in Sutherland, The Professional Thief (1937).

47. Rewards have been mentioned. Do they figure in the mind as among the familiar fields where variation exists between general doctrine and cases? If not, they ought to begin to make the point. Substantial performance is taught commonly, and thought about, in terms of building construction, and forfeiture. Has this been cleanly integrated with the degree to which in Sales contracts, there has been sub rosa introduction of substantial performance by widening the meaning of "description" in the case in hand? Sales, on the mercantile side, needs an explicit substantial performance rule, and is getting pieces of it, impredictably. On the other hand, substantial performance is still considered by very careful Contract thinkers-e.g., Patterson-to apply to non-"express" conditions, even in building construction. If such be an accepted formula, it still, as a formula, gives no guidance, so long as courts have their full freedom to $d u b$ 
Every close observer has also become aware of deeper cutting divergences-divergences in so-called "application" of rules verbally alike, leading, according to transaction-type and issue, to diverse outcomes of cases. If we view these one by one, and only one by one, with our minds fixed upon some hypothetical and never yet proved unity of Contract law, then one by one, as we perceive discrepancies, we discard them. We forget them. We do not count them. We do not gather them. Selective observation of the cases has become somewhat too lightly our general way of working, where there exists supposedly satisfactory doctrine. Peculiarly, I fear, in Contract. WV accumulate and cumulate only those decisions which work in favor of accepted current general doctrine, or something close to it. Cases which talk current Contract doctrine: these are gathered and indexed, heaped up in availability. Cases which do not, are scattered, unindexed, lost to mind. The resulting picture of how far current Contract doctrine is the case-law rule, of how far it is a guide to either prediction of outcome or to wise decision, that resulting picture is considerably askew. It misleads counsel and client. It even misleads judges, some times-and unpredictably. This strikes a commercial lawyer as regrettable. And as unnecessary.

Now such remarks might be waved aside as being merely a ballooning into pseudo-importance of those trivial discrepancies with which we are all of course familiar. Or it might be cold-storaged as merely one more expression of "the realists" " phobia, in their neurotic particularism, against the general and the logical elements in law, or even in case-law.

"express" or "implied" whatever may seem (alternatively) demanded by precedent or demanded by justice. The New York warranty cases are in point. Warranly, II. But so, in the construction field, is Jacob and Youngs, Inc. v. Kent, 230 N. Y. 239, 240, 129 N. E. 889, 890 (1921). The clause there read: "all wrought iron pipe must be well galvanized, lap welded pipe of the grade known as 'standard pipe' of Reoding manufacture." (My italics.) Now I refuse to believe that the insertion of a comma and an "and" after pipe, could have done much more than turn an advance prediction of perhaps 4-3 into an equally gambling prediction of perhaps 3-4. Both, in advance, most doubtful. For at least two of the votes, where one was enough to swing tho court, moved on totally different grounds, the vote in favor of plaintifi conceding "express"ness of condition, the vote in favor of defendant resting on the adequacy of an action in quasi-contract. I adduce these non-documented statements at this point not to explain that holding, but to help foresee or guide happenings still to happenfor that is where things legal count most. Mfy own guess is that accepted doctrine, with the ill-chosen term "express condition," had phrased the real issue rather unfortunately for the juice behind the issue. Which led to uncertainty, for counsellors, as to outcome; and to uncertainty, for good and careful judges, as to both what case-law directed, and as to what was wise.

Other more factually specific situations will be discussed in following articles.

I choose one here which is factually general: no type of rearrangement of a going deal between contractors has been sharply distinguished in explicit orthodor doetrine, with any tlarity, from intiation of a prospectiec deal. The cases show at least material differences as to offer and acceptance, consideration, statute of frauds, and legality. 
But even a hurried glance at the history of Contract doctrine must counsel against such light misdisposition of the matter.

\section{One "Great" Doctrinal Pseudo-Achievement as a Warning}

It once seemed a great achievement to "reduce" consideration to the formula of bargained-for detriment to the promisee.48 As thus "reduced," the principle threatened all claims by beneficiaries, some of which the courts had been moderately busy enforcing. ${ }^{40}$ These days, that does not seem to have offered any gain in policy; certainly it was a departure from cases frequent enough to induce a change in typical life insurance beneficiary clauses. The principle threatened in addition all enforcement based on subsequent reliance. That was a departure from a goodly body of cases; these days it does not seem to have offered too great a gain in policy. ${ }^{50}$ It is beginning to be clear, moreover, that the broader principle which was so "reduced", rests, itself, on very dubious over-generalization. Promises to make a benefaction are in fact very commonly enforceable in our case law $; 5$ and in my own opinion, most of those

48. Langdell did this job rather to any admirer's satisfaction. Holmes gives the job the accolade: "and only of late years has it been reduced to the universal expression of detriment to the promisee." Collected Legal Papers (1921) 218. (Holmes, though at times in Contract matters materially more interested in system than in sense, tried repeatedly with shrewd strokes to place the ball where it belonged. See notes to What Price Contract? An Essay in Perspective (1931) 40 Y ALE L. J. 704). N. Isaacs' admiration for such achievements of Contract systematization in the 19th century, expressed in Standardizing of Contracts (1917) 27 YALE L. J. 34, seems to me to have waned materially as he came to deal with the facts about business agreements today. Williston, however, still recorded the influence of the great achievement, when he created for Restatement and Text a category: "Contracts Without Consideration." (In this lies as fine a compromise between honor to the past and furtherance of caselaw reform as has ever been in our system conceived.)

49. Am I wrong in thinking that cases refusing claims to moderately clear beneficiaries are rarish in pre-1870 America, and that cases enforcing such claims are frequent enough to suggest both a need and its recognition? Or do I overgeneralize from what I know happened in New York?

50. As to the departure, I reserve detail for real discussion. Comparative dates become important. Cases dealing with initiation and with readjustment require special treatment. The kind of case which was lying around and was departed from is, inter alia, the kind of case which Shattuck has been turning up in his Gratuitous Promisesa New Writ? (1937) 35 MrCH. L. REv. 908. Only that the author there has been misled by the verbal result of this supposed principle into dealing with a very old and moderately well-sustained body of decision as if it had something New about it.

51. Here lies the heart of a full and documented paper. It rests in part on what Shattuck, cited supra note 50, perceived as fact, but conceived as queer. The note in (1938) 23 CoRs. L. Q. 310 perceives a trend, sees it also as queerish, and then, while facing the cases squarely (as does Shattuck) tries, with a touch of vigor, to find a way around what seem to be some implications. Compare also Seaver v. Ransom, 224 N. Y. 233, 120 N. E. 639 (1918). See the later papers of this series. 
which are, should be. But note: when the courts enforce a promise to make a benefaction, they do not say: "This promise ought to be and hereby is enforced, although in no common or sane meaning is it other than gratuitous and unexecuted." They say: "Of course, in our law, gratuitous unexecuted promises are unenforceable;" then they enforce the one in hand. If this happens along any describable lines of moderate regularity, then a statement of the lines and degree of that regularity is a statement of the rule of the case-law. ${ }^{.2}$ And to put forward such a statement is not to depart from principle. It is merely to make clear that the so-called principle in question is not a full-fledged honest and clean principle of case-law, but is instead an over-formulation or misformulation of the principles of case-law. To mask an inadequate formulation under the disguise of Principle may save it for a time from detection and unmasking, and may mislead students and even courts, and in the case of small fields where emotions do not stir or interests do not cumulate may even in time allow the masker to squat his way into prescriptive rights-but such masking does not make a formulation into a Principle, nor does the masker's success in being called by that name: he must get results, on cases, in decisions, and with some regularity, else he remains pseudo. When his acceptance would lead to objectionable results, even courts which are most polite to him show singular skill, much of the time, in avoiding acceptance of his orders or advice. ${ }^{83}$ It is the case law scholar's task to note and cumulate these instances along with those which, under the influence of accepted doctrine, the digest makers gather accessibly. We need, in the masquerade of case-law, and of Contract case-law in particular, to go on spotting the imposters. Is it not queer that, for instance, the great "principle" of detriment, etc. (which does not even effectively cover that huge body of contracts, the bilaterals) ${ }^{54}$ which has proved inadequate as a negative test at every turn, and inadequate as a positive test again and again ${ }^{53}$-is it not queer that this pervading "principle", although unmasked, not only maintains a good deal of social acceptability himself, but raises so few doubts in conventional minds about his company?

\section{Building Good Case-Law Princtple-or Rule}

Yet most of such or any principles of Contract have bars sinister upon their hidden scutcheons. The sound and legitimate way of bringing a

52. The If is the point, and one to be proved by cases.

53. Eno, Price Movements and Unstated Objections to the Defective Performanee of Sales Contracts (1935) 44 YALE L. J. 782.

54. As Corbin has well noted, Cases on Contracts (2d ed. 1933).

55. See my What Price Contract? An Essay in Perspective (1931) 40 Yale L. J. 704,741 , et seq. 
principle of case-law (which has only very remotely to do with a principle of justice $)^{56}$ into the world is to canvass all the case material which the proposed principle would cover. Nothing can wisely be thrown out as "wrong" until it has been looked over to see why its presence as decision does not shed doubt on the validity of the proposed formulation as being a principle at all. Such a line of attack demands of the claimant "principle" that it bring not only order, but wisdom; that the classification on which it rests be a significant classification, and that the criterion it sets up be a significant criterion, over substantially the whole of the material classified. In the case of the Statute of Frauds, e.g., the following might promise good results as a clarifier of when cases verbally under the Statute would be (and where "would" is doubtful, should be) taken out: "If independent of testimony about oral transactions there is in the court's opinion objective indication of action by the plaintiff which is really hard to explain unless the defendant made some kind of promise, or if the defendant has in the court's opinion received so much benefit at the plaintiff's expense that he will not outrageously suffer if the plaintiff puts over a lie, but the plaintiff will outrageously suffer if he is telling the truth, then the plaintiff may go to the jury on whether an oral promise was made, and if so, in what terms." This looks like working sense; it patently fits many of the cases which spring to mind; it patently fails to fit others; most of these others one does not like. But surely such a formulation would not work out on an employment contract for five years; nor should it, within the policy of the statute. I do not want to be tedious, but I believe the illustration to make the point that what may check up very well in one portion of a somewhat variegated landscape, or even in several portions of it (say suretyship and land) may fail wholly to either check up or be desirable in another portion of the landscape included arbitrarily in a map whose borders have been dictated not by examination of the full data in the particular situation in hand, but by some general notion merely that such is the landscape unit-for any purpose where the contrary is not demonstrated. At present writing Contract carries, to most of us, a presumption of unity of rule, a presumption also that the rule works out to uniform results, unless the contrary is demonstrated in the particular case. I hold, despite the language of courts, writers and Restaters, that no case-law foundation has ever been laid for such a presumption. I urge that there is a foundation, in all probability, to be laid for many close-to-universal rules of Contract, and to be laid out of case-law. But I do not know what those rules may be. Neither does any other Contracts scholar. Sales, insurance, employ-

56. General jurisprudential discussion might, in our legal system, run comfortably without touching the case-law of Contract. I propose to challenge any such possible discussion at both ends: (A) I want to touch the case-law of Contract. (B) I want to limit my remarks to the case-law of Contract. 
ment, real estate brokerages, construction deals, and what have you, have been drawn to set up Principles of Contract. Exceptions come where something somewhere got too uncomfortably in the way. Our rules and principles of Contract, as we have them, do not rest on clean inductive work, nor yet on clean analysis of significant factors in a confusion. They represent, instead, a swell idea which never has been adequately tested on the modern cases.

Corbin has probably come closer to the testing than any other caselaw scholar, living or dead. As one watches his writing, one-observes two exceedingly interesting phenomena. Two phenomena exceedingly promising, as well. First, he never lets go of the cases. Second, he never lets go of the need for clarification-for every grain of clarification which the cases will allow. His earlier work looks toward clarification of the field, and the setting up of a conceptual frame-work. But his conceptual frame-work (built on and beyond Hohfeld's) was in the earlier mature work essentially not one of substance, but one of vocabulary, to enable statement of substance. ${ }^{57}$ Meantime, the cases were used to tear down or challenge current over-statements, whosesoever, and his classes were taught that to the degree of uncertainty which might exist, flat and absolute pseudo-rules were unsolid things to rest on. What one may call the middle period of the mature writing grows increasingly concrete, and deals with substance. Always, again, with most careful emphasis upon the cases. With more emphasis than before upon their more concrete phases. Moving, now, into narrower and more intensive case-exploration: third party beneficiaries, let us say, in English lazu, or in construction bonds, or in construction bonds in federal courts, narrowed by jurisdiction, or narrowed by situation-type, or both; but each narrowing significant, as proved by the results. ${ }^{53}$ This was a period of drilling, hole by hole, to test formations in the field, to find out whether it was uniform, and how far so, and with what theretofore unsuspected matters to watch for. The end product, remedy, came in then for hardheaded study, along with operative facts and "construction." The final product has been synthesis, still with hand, eye and boring drill directed to the case-results. "The more I read the cases, and the more thoroughly I meet what is there in the great body of them, the less certain I grow about theories, including my own, that were based on just a few of

57. I refer here to such articles as his Offer and Acceplance, and Some of the Resulting Legal Relations (1917) 26 Y ALE L. J. 169, and his first "Consideration" and "Third Party Beneficiary" and "Conditions" material. Compare Radin, A Restalement of Hohfeld (1938) 51 HARv. L. Rev. 1141.

58. Stuff whose clean doing, and therefore clean reading, is there to be seen and has to be used, begins with such papers as Contracts for the Benefit of Third Persons in Connecticut (1922) 31 YaLE L. J. 489, and moves on to such as Third Parties as Beneficiaries of Contractors' Surety Bonds (1928) 38 Y ALE L. J. 9. 
them. It is the first chapters of my book, where I thought I had really ripened my ideas, which are giving me the most trouble now. Unthinking one's inadequate results, and rethinking the material, is tough work." Not for Corbin that anecdote of Vinogradoff, when that fine but tired scholar is said to have been faced with unchallengeable evidence that some of his work was wrong. Not for Corbin, any alleged: "Young man, you are asking me to rethink all I know." Corbin's book will be the first sustained testing of the general lines of accepted Contract theory which we have ever had. I anticipate a most sympathetic testing. I also anticipate considerable embarrassment for both general and particular lines of orthodox Contract theory.

Dissatisfaction with the current of orthodox theory-summed up in the sequence of Langdell, Williston, Restatement, Williston and Thompson-has not been absent. The more adequate expressions of dissatisfaction have appealed to the cases as the test. Before the Restatement, there had been shrewd inquiries by such as Patterson, McGovney, Ballantine, Costigan,-to say nothing of Corbin. I think it fair to say, however, that none of these (as of their date of writing) challenged the essential foundations of the then existing layout. Much more, they refined and reformulated substantially within a structure given. Pound came closer to a challenge, ${ }^{60}$ but stopped short of case exploration to see what could really be done as a substitute. When individual writers have attacked consideration or the statute of frauds, it seems to have been rather on grounds of policy, with orthodox doctrine presupposed to be existent and potent. ${ }^{61}$ Clean breach with the what had aforetime been

59. Some such words, which are my best guess at the words he used, I heard from him a few years back. Corbin began not from Langdell, but from Parsons!

60. Corbin's work is known. It is labelled Contract. Patterson's, both in article and the often, and this time, more important field of Case-book, is known. McGovney has some of his nicest stuff recorded in SELECTEd REAdings oN THE LAw of Contracts. So has Ballantine, although he has also spread insidiously sound influence over his book for bar review. Costigan's CASE-Book simply stands in beauty-with due deference to his articles. But it may be suggested that some of Patterson's or Goble's work is probably labelled not Contract, but "Insurance," and some of Costigan's, is labelled Trusts, and some of Havighurst's is perhaps not labelled at all with any conventionally effective device which will draw it into discussion of Contract rules-as Fuller's and Mason's, and Gardner's, may not be, for varying reasons-and it may be suggested further that the unlabelled stuff can come as close and closer to the juice than does the labelled. Radin's Restatcment of Hohfeld (1938) 51 Harv. L. REv. 1141, begins by making a point: the real point that the behind-the-cases "theory" may have real stuff. It may. Some of it must (although in posse). Meanwhile we search, in Case-Law. Some of our finer searchers are named above.

Pound's "closer to challenge" is found first, so far as my reading goes, in his P11tL. OSOPHY OF LAW (1925).

61. Enough is cited in Bogert and Britton, Cases on Sales (1936) on the Statute of Frauds; Consideration has long been a rather indiscriminate object of attack. Let me cite here Lorenzen's rather moderate Cansa and Consideration in the Law of 
regarded as "orthodox" turned up rather in the greater and sillier, perhaps, reaches of the "bargained for detriment" principle mentioned above, and in the factually minor case of attempted revocation of offer for a "unilateral."

But within the last decade a wholly distinct line of worry has been making itself vocal. It involves a challenge to the very structure of orthodox Contract doctrine. The precursor was Walter Cook, following Hohfeld's jurisprudence on the relation of equity to law into a casebook merger of quasi-contract and equitable remedy. ${ }^{62}$ This Patterson followed with a marriage of Cook's Remedy ideas with Contract-theory, ${ }^{, 3}$ whose results Orthodox Theory has yet to take full account of. The Restatement of Restitution shows the influence of Keener, Woodward and Cook, without attempting any indelicate and thorough integration into Contract theory. ${ }^{64}$

Meantime Gardner had looked over Contract as a Whole ${ }^{\text {es }}$ (Corbin had already begun the orthodoxly outrageous marriage of Offer and Acceptance with Conditions ${ }^{68}$ which Sharpe ${ }^{67}$ and various student editors have blessed and furthered) $;^{68}$ Gardner, if I read him right, was shocked at the disorder and disharmony and un-thought-throughness which he found in the doctrines gathered under the label Contract. He attempted a restatement of Principles in Hierarchy; a beautiful and (for our modern case-law) a novel idea; both method and substance deserve attention which they have not received. The method not only of carefully formulating a principle, but of carefully formulating not a single one ad hoc, but a number of competing principles, in the light of a whole picture; and then not of simply posing them in competition, but trying to arrange machinery for choice among them: this is almost as fine a contribution to juristic method as is Corbin's relentless and unremitting search for and of the cases and his insistence on making any theory square with them. In direct application to the law of Contract, Gardner's principles are suggestive, but they need heavy case-law study to develop whether they are principles of Gardner or of case-law. To be a principle of case-law, rather than merely for case-law, an alleged principle must bring its secta, it must number them off, it must measure their number

Contracts (1919) 28 YALE I. J. 621, and then refer merely to my ensuing article. Because this matter, like some others of those previously referred forward, is a bit delicate to deal with in advance.

62. CoOk, Cases on Equity (1932).

63. 2 Patterson, Cases and alaterials on Contracts (1935).

64. See Patterson, Book Review (1938) 47 YALE L. J. 1420.

65. Gardner, An Inquiry into the Principles of the Low of Contract (1932) 46 HARV. L. REV. 1.

66. Corbin, Offer and Acceptance, and Some of the Resulting Legal Relotions (1917)

26 YALE I. J. 169; one of the most essentially disruptive papers ever published.

67. Sharp, Book Review, (1936) 4 U. of CrI. L. Rev. 30.

68. E.g., Comment (1933) 33 Cor. L. REv. 463. 
and worth against the opposition. It must also show cause for not letting the opposition secede into a separate category, with a different principle, and for not admitting some other phrasing of issue as one more vital, which would more further harmony.

Gardner's line of attack on remaining disorder in the field (which for all difference in method and expression is akin to Michael and Adler's work toward logical statement of the law of Evidence) ${ }^{60}$ is both like and unlike the more general current of modern dissatisfaction with Contract rules as currently accepted. Both doubt. Gardner seeks resolution of doubt by further arrangement and order. The bulk of doubters, troubled as Gardner has been, have yet found their troubles concentrating rather on the cases. Into these they have bored. Each boring yields new evidence that our accepted formulations of the rules of law in the field of Contract do not express the cases. Each boring, if one puts the borings together, creates or strengthens an impression that a re-analysis of basic concepts would materially further the statement of case law, and indeed that the courts in action have been materially wiser than has been the dictuming of either the scholars or the opinions. The impression is, in a word, that large portions of currently accepted Contract doctrine neither are law, nor ought to be law.

I refer to such work as that of Havighurst, ${ }^{70}$ Sharp, ${ }^{71}$ Fuller and Purdue, ${ }^{72}$ Shattuck, ${ }^{73}$ Mason, ${ }^{74}$ and Law Review Notes now beginning to rise in number beyond counting on the fingers. I include work of my own.

69. The Nature of Judicial Proof (1931); Micitael and Apler, The Trial of AN IsSUE OF FACT (1934).

70. Havighurst, Services in the Home-A Study of Contract Concepts in Domestic Relations (1932) 41 Yale L. J. 386; cf. Havighurst, Cases on Contracts (1934).

71. Sharp, supra note 67.

72. The Reliance Interest in Contract Damages (1936) 46 YALE L. J. 52, 373.

73. Shattuck, supra note 50.

74. A study carrying, to my mind, into closer statement the results gunned for by Fuller and Purdue, in Mason, $A$ Theory of Contract Sanctions (1938) 38 Coc. L. Rev. 775. I hold with Radin, supra note 67, and, shall I say, with Morris Cohen, as the representative of all logicians (passim in Cohen's implication, and many times in his expressions) that behind action there are lines of action. From which it follows that statement, adequate statement for future guidance, of such lines of action, is a caselawyer's job. The language used by Fuller and Purdue, or (and to my mind better), by Mason, is wholly unfamiliar to case lawyers. It may, therefore and of course, fail to make any dent upon case-lawyers. It may be further cursed, even when otherwise persuasive, by having attributed to it the notion that it is Civil Law Stuff. But to me both writers seem to move toward more accurately stating our own Case-Law Results. And, by test, I am very sure that Mason's remarks have no remotest relation with anything which Civil Law Theorists have been spending words on. Mason's Frencr Case-Law talks the French Law in terms of Case-Results, regardless of the words of the writers. As Ours ought to. 
This paper is intended as an argument-to be followed by successive demonstrations-that where doctrine does not square with case-results, that doctrine is not law, in a case-law field. It is intended to pave the way for a recanvassing of things now known about the case-law of that field of "Contract" which has to rest on cases; past and future. It is intended to suggest the utility of gathering the thus far one-by-one insights and explorations into some attempted whole. It is intended as an introduction to a series of papers the appeal of which will be to the decisions of the courts on cases, the effort of which will be to present rules of law instead of formulae of superstition about law, and the reliance of which will be in major part on the case-study already done by a rather grand succession of named and anonymous writers who concur with Arthur Linton Corbin on the point that in a case-law field the theorists' intellectual constructs have as their first objective to state accurately and neatly what the courts have been doing. That theorists are to do criticism only after stating accurately and neatly what it is that they are criticizing.

As planned, the series includes a study on Offer and Acceptance, one on Form and Formality, one on Consideration, one on Scope and Meaning of Contract-and jurisprudential appendices. The impulse and analysis of Langdell, the further development and clarification of Williston, the caseless Restatement of the Law of Contract: These seem to me at clear variance with both the decisions and with sense, on too many points for comfort. The five volumes of Williston and Thompson which I have thus far read contain, to my reading, a desperate, though often skillful, effort to make non-law look like law. The fault lies, in my belief, in Langdell's having started with cases of Elizabeth's time, which was a period of change and worry, but having started with little appreciation of the movement with which that period was instinct, and equally little appreciation of the relentless fact that America, 1870 to now, was not and could not be England of any date.

But it is not causation which is to be discussed. It is case-law. Caselaw. Over the long haul, every case-lawyer yields to any course of actual decision. There is no value in postponing recognition of the fact.

In the further papers, which will have to do with specific and relatively concrete Contract doctrine, the case-discussion will be thorough. Indeed. this paper was written after two of the others had been prepared, in sudden worry that some folk might think an attack on pseudo-rules, of case-law (because such pseudo-rules did not help counsellor or judge, as tested by the cases) to be an Attack on Rules, or on Concepts, at large. In worry, too, lest some folk might think that taking the course of decision (if there be one) as determinative of the existing rule of caselaw would indicate a lack of interest in good, or wise, or ethical, rules. Whereas, for instance, so long as judges some of the time treat printed forms as if they had been deliberate "writings" deliberately preparec 
as bargained-base, no critique of their action can be intelligent without some de facto understanding either of how often they do, or else of when they do and when they do not.

Neither understanding of case-law, nor intelligent criticism of caselaw, is possible, without first knowing what case-law is. In Contracts, superstition is rampant. Rampant superstition is unfortunate, because it has results-sometimes. Whereas, in transaction-law, there is a certain value in a modicum of knowing in advance where one will be at. The first job of case-law rules is to give such guidance. In the process of being accurate, it often happens that they uncover implicit wisdom.

\section{Appendix ON THE JURISPRUdence OF Certainty}

Goodhart labored mightily to establish a single relation between cases and rulcs. Determining the Ratio Decidendi of a Case (1930) 40 YAlE L. J. 161. And we have rather a clearly articulated set of rules for "determining" what is all that a case held -when we do not like the case; though Morgan's horse-sense breaks through, when he presents them. The Study of Law (1917). Pound sees and responds to the ideal; he also sees and responds to the horse-sense; then the ideal triumphs, as he turns to the obscurantist phrasing: "techniques [plural, sic] for developing and applying," etc. If different techniques are present and approved, and lead to different results, then we need guidance on which of them will be applied. Frank cut into the matter by exaggeration from the other end: real and definite certainty our authoritative scheme does not give us, out of the authoritative techniques above. But as I have' elsewhere insisted, if some working approximation were not given, somewhere in our scheme of things, then revolting jurisprudes like Frank and Arnold would not be valued for their legal advice, nor would they dare to undertake the argument of a case. Arnold's suggestion that leeway in available rules so wide as to seem almost silly provides a nected discretion for the court, has juice. The Role of Substantive Law and Procedure in the Legal Process (1932) 45 HARv. L. Rev. 617. But implicit in that suggestion is a double additional suggestion: first that something guides the use of that discretion, with moderate efficacy; and second, that getting such guidance into working words is going to be one tough job. Both are points on which I think Pound reacts with singular closeness to Arnold. Pound sees the need of the guidance, feels it ought to be clothed in working words, and can't quite find those working words. Only on this basis can I understand his constant insistence that the guidance is actually there, in the rules we now have; qualified by the very useful concept "standards," and by the less directly useful one: "techniques." But the "standards" are effective guides less because they are legal standards than because they are part of the working body of our culture at large; and the "techniques" work out with a modicum of predictability because American lawyers are enough alike to afford a business man's gamble on what an unknown judge (and as Pound well points out, even more predictably a bench of judges) may do. There is vitality in Levi's observation that it is to the extent that we size up similarities and dissimilarities somewhat alike that we get a working judgment on outcome of cases. And even the seemingly devastating and thoughtful analysis of Underhill Moore and his co-workers is really devoted to showing an important remaining degree of certainty, not to showing that it does not pay to hire a good lawyer to turn loose with The Lawyer's Law.

Out of all this comes the suggestion that the jurisprudes who have been canvassing the part played by explicit accepted rules of law in our legal system have managed a good deal of non-joinder of issue, this past decade, but that all of them have been talking a deal of sense about whatever portion of the picture they happened to be talking of, 
and that mostly they have talked too broadly. I find enough dissimilarity between the situation under a statute and that under case-law rules to make it vise to sever the discussion. I find enough dissimilarity between the situation under a really first-rate case-law rule and one of the emptier formulae which pass as such to force severance of discussion. Accepting, with Patterson, as any sane thinker must accept, the fact that the words of an accepted rule help focus attention and issue, and call up context, and even lead to deliberate effort to exclude.certain othervise relevant matters from effect on judgment, I still cannot see how any one can study, side by side, a situation where the accepted case-law formulae neatly focus and one where they mis-focus what it is all about, without perceiving that in the latter case the situation is less predictable, very materially less predictable. Even when "guided" by badly drawn rules, courts repeatedly, and with no full measure of predictable result, squirm for Justice's sake-and the wherewithal to squirm handsomely is well provided in the authoritative ways of worling. This is the meaning of Hutcheson's Hunch, and of Fuller's animal in a most discomfortable enclosure.

In our contract law, it means that many formulae need redoing.

But above all, for Jurisprudence, it means that we must try to apply the procedure which we do in reading opinions for their doctrine: read the article with an eye to the matter under discussion. Above all, I hope we can begin the elimination from our reading of an alarmist interpretation of dicta. It is regrettable that Arnold, attempting a point about law and jurisprudence, develops a parallel from theology in such fashion as to simply outrage a good Churchman like Kennedy. Yet the procedure of hunting such parallels is sound. Nowhere in the explicit doctrinal literature of our law vill one find as cogent an indication of one vital legal need, that of uneamed favor to the weal: and helpless (alongside or above Justice) as one gets from the Church's teachings about Our Lady. Our Lady's Tumbler has more to tell, for Jurisprudence, than the history of moratory legislation, or four treatises on Individualization of Treatment.

Certainly, for this series of papers, I trust that attempted observation of the actual workings of our legal institutions may not be obscured by any departure from more conventional ways of talking about them. If eminent writers assure us that a case can only hold, let us say, either its announced ratio decidendi or a rule covering more narrowly its precise holding, I should be slow indeed to doubt their views as being part of our case-legal system. Certainly not, if I found, as I do find, courts acting on those lines. But if, despite such assurances and such action, I also find courts acting very difierently, I am forced to conclude that the expression of a narrow view of precedent is only partial; and also that the going doctrines of precedent, alone, give no clear guidance. Institutions, including legal institutions are what they are, and what is said or believed about them is only one part of what they are. And it would be unfortunate for the idea to gain currency that would-be realistic students had an obsession for the ugly because they find the conventional rationale of an institution to be a partial one, which gives insdequate guidance. Such an idea attributes ethical and esthetic values to heretofore conventional rationale which in case-law, at least, are seriously open to question. There is much to be said for the proposition that the going institution has been a deal viser than have its partial rationalizers; and, I think, a deal more esthetically satisiactory. Compare Brasrabe Busn, 128 et seq. In the work of the judges, seen whole, lies case-law; there lie, too, the case-law rules of Contract. When one of those known as realistic students of law heares a snowball at a top hat, he shows impatience and perhaps bad manners, but the inference is not-even if he hits and spoils the hat-that he is undermining the institution of hats or of clothes at large. If the top hat has purported to be a full deseription of the head, there is even something to be said for using snowballs on it, as furthering understanding of and appreciation of the head. I think we have too many top hats of rather useless lind worn in the case-law of Contract. But I shall try to ask, in gentlemanly manner for their removal and examination. 